\title{
Qualitative parameters of pleurotus ostreatus (jacq.) p. kumm. mushrooms grown on supplemented spent substrate
}

\author{
M. R. Picornell-Buendía ${ }^{1, *}$, A. Pardo-Giménez ${ }^{2}$, J. A. de Juan-Valero ${ }^{1 \dagger}$ \\ ${ }^{I}$ Escuela Técnica Superior de Ingenieros Agrónomos de Albacete. Castilla - La Mancha University. Campus \\ Universitario s/n, E02071, Albacete - Spain. ${ }^{2}$ Centro de Investigación, Experimentación y Servicios del \\ Champiñón (CIES). C/Peñicas, s/n. Apartado 63. 16220 Quintanar del Rey. Cuenca. Spain. ${ }^{*}$ Corresponding \\ author: MRaquel.Picornell@hotmail.com
}

\begin{abstract}
In this paper, the agronomic viability of Pleurotus ostreatus (Jacq.) P. Kumm. is studied by reusing the spent substrates previously used in crops of the same mushrooms. To this substrates are applied commercial nutritional supplements $\left(\right.$ Calprozime $^{\circledR}$, Champfood ${ }^{\circledR}$ and Promycel $^{\circledR}$ ), to research their potential use as additives together with wheat straw (WS), calcium sulphate and calcium carbonate at different doses. After the physical and chemical characterization of the substrates, we evaluated the qualitative production parameters in one flush. The mixture of wheat straw (WS) (3,000 g) and spent Pleurotus substrate (SPS) (3,000 g) supplemented with $120 \mathrm{~g}$ of each of the commercial supplements (Promycel ${ }^{\circledR}$, and Calprozime ${ }^{\circledR}$ Champfood $^{\circledR}$ ) are substrates that promote red-green $\left(\mathrm{a}^{*}\right)$ and yellow-blue $\left(\mathrm{b}^{*}\right)$ chromaticity in harvested mushrooms. This manuscript presents the results obtained in an experiment where different supplements were used to enrich substrates composed of wheat straw and spent substrate. Qualitative features of Pleurotus ostreatus mushrooms were evaluated.
\end{abstract}

Keywords: Pleurotus ostreatus (Jacq.) P. Kumm, spent mushroom substrates, edible mushrooms, agricultural wastes, qualitative parameters

\section{Introduction}

The potential production of edible fungi is promising in the world market, as the current production is not sufficient to meet the demand. In general, all producing countries are also importers because consumption is very high. Nutritionally, these species have moderate amounts of high quality protein, contain all essential amino acids, and are rich in lysine, leucine, $\mathrm{C}$ and $\mathrm{B}$ vitamins, minerals and trace elements. Furthermore, lipid levels are low, the ratio of saturated to unsaturated fatty acids is low, they contain relatively high amounts of carbohydrates (approximately, 32\% of carbohydrates are hexoses, $1.16 \%$ are pentoses and $4.20 \%$ are soluble carbohydrates), and most species have high amounts of nutritionally valuable fibers (Chang and Miles, 1997). Complementary to its nutritional properties, 
there are various health benefits known in the fields of medicine and therapeutics such as, anti-tumor, antibiotic, antifungal, and antiinflammatory effects. Additionally, they are hypocholesterolemic, promote a healthy immune system, and have been widely used to treat cancer and HIV (Brizuela et al., 1998). Approximately, there are around 300 species of cultivated mushrooms, but only 30 have been domesticated and just 10 are commercially grown. The most important cultivated mushroom worldwide is Agaricus bisporus (Lange) Imbach, followed by Pleurotus ostreatus (Jacq.) P. Kumm. and other species of the genus Pleurotus; Lentinula edodes (Berkeley) Pegler is third and other edible fungi are making headways in the market.

The reason for this growth is because of the characteristics of the genus Pleurotus species (Sánchez, 2010). They have excellent organoleptic qualities, are easy to grow on a wide variety of substrates within a wide temperature range, and have a great potential in bioremediation processes. Moreover, little initial capital is required to establish warehouses for cultivation. The preparation of the substrate does not require a lengthy complex composting, nor an application of a casing at the end of mycelial growth (such as white mushrooms), or a water immersion or dipping phase (such as shiitake mushrooms). Unlike white mushrooms (Agaricus bisporus (Lange) Imbach), these do not require a chemically selective substrate because they can grow in nutrient media with a $\mathrm{C} / \mathrm{N}$ ratio between 30 and 300 (Rodriguez Barreal, 1987; Garcia Rollán, 2007). However, they need to grow in a specific biological environment with accompanying flora to protect and promote growth. Approximately, 13,500 t of this fungus are produced in Castilla - La Mancha (Spain) (67\% of the national total) (Picornell et al., 2010). The
Mushroom Growing Sector in Spain generates about $500,000 \mathrm{t}$ of spent compost, while the EU, as a whole, produces more than $3.5 \cdot 10^{6} \mathrm{t}$ (Picornell et al., 2010). This lignocellulosic material called spent mushroom substrate can be used in various fields of agriculture (Rinker, 2002). However these uses are not enough to take advantage of the high volume generated annually, which accumulates in collection centers located in production areas of Spain. Furthermore these spent substrates are potential contaminants, not to mention, a waste of energy. $P$. ostreatus has specific enzymes capable of degrading cellulose, lignin, phenols and polyphenols to $60 \%$ of the original content of the spent substrates. Currently, cereal straw (wheat in particular), with increasing constraints in availability and price, is virtually the only material used at an industrial scale for the production of $P$. ostreatus in Spain. The feasibility of using highly available alternative materials at a low cost is a line of research with great technological interest to keep up with improving productivity and reducing processing costs (Pardo et al., 2007; Picornell et al., 2010).

Although this fungus can be grown on virtually any lignocellulosic substrate (sawdust, cereal straw, etc.), the spent substrate which generates high quality fruit bodies for P. ostreatus mushroom growing is the trunk of Quercus humboldtii Bonpland specie (oak) (Garcia Rollán, 2007). Commercially, in most industrial exploits, 2-4 cm long (Sánchez, 2010) pieces of winter cereal straw (wheat, barley, and rye) is used in the substrate container for the production of Pleurotus genus and others, such as Pleurotus eryngii (DC.: Fr.) Quel., Pleurotus sajor-caju (Fr.) Singer, Pleurotus pulmonarius substrate (Fr.) Quél., etc. Biodegradation of these cellulosic residues by 
Pleurotus spp. growing depends on the production of hemicellulases, cellulases, and ligninases enzymes (Kurt and Buyukalaca, 2010). These enzymes, among others, turn and degrade long and insoluble components of lignocellulosic materials into soluble components of low molecular weight that are taken by intracellular enzymes from fungi for their nutrition. Additional, enzymes play an important role in the growth and development of fungi. However, the lignocellulosic materials are generally low in protein content with insufficient values of nitrogen, phosphorus, and potassium for mushroom cultivation (Vijay et al., 2007). While Ilbay (2004) reports that the better spawn and higher yields of Pleurotus eryngii are obtained with organic substrates supplemented with $1.10 \%$ of nitrogen, any higher percentage of nitrogen inhibits both the linear growth of the mycelium as well as the biological efficiency.

The aim of this work is the qualitative agronomic evaluation of the spent Pleurotus ostreatus substrate (SPS), and its mixture with WS in different proportions (such as lignocellulosic sources in new growing cycles of $P$. ostreatus) and unsupplemented and supplemented with $120 \mathrm{~g}$ of each of the tested commercial supplements (Promycel ${ }^{\circledR}$, Calprozime ${ }^{\circledR}$, and Champfood $\left.{ }^{\circledR}\right)$. This experiment intends to find the different treatments with SPS that improve the quality of mushrooms, achieved with WS, and whether the added supplements produce favorable agronomic results.

\section{Materials and Methods}

\subsection{Analytical methodology for the characterization of materials}

For the characterization of raw materials and processed substrates the following parameters were determined: moisture (MAPA, 1994), pH (Ansorena, 1994), total nitrogen (Tecator, 1987; MAPA, 1994), ash (MAPA, 1994), organic matter (Ansorena, 1994), C:N ratio, crude fiber (ANKOM, 2008), crude fat (ANKOM, 2009), nitrogen free extractives (NFE) (González et al., 1987), cellulose, and neutral detergent-soluble (NDS) (ANKOM, 2005, 2006a, 2006b). Furthermore the exploration of mites (Krantz, 1986) and nematodes (Nombela and Bello, 1983) was performed.

\subsection{Preparation of substrates and experimental design}

The corresponding experimental design of this trial was a Balanced Plan Factorial Design 3 x 4 with six replicates (randomized block factorial with two factors). Factor 1 corresponded to the type of base substrate used (WS, WS + SPS, SPS), and Factor 2, corresponded to the type of commercial supplement used (no commercial supplement; Promycel $^{\circledR}, \quad$ PRO $^{\circledR} ; \quad$ Champfood $^{\circledR}, \quad$ CHAM $^{\circledR}$; Calprozime $\left.^{\circledR}, \mathrm{CPZ}^{\circledR}\right)$. With these two factors and their corresponding levels, we established twelve different treatments and two commercial substrates (6 $\mathrm{kg}$ bag and sack in commercial format) of Champinter (Villamalea, Albacete) for a total of fourteen different combinations to be studied.

Gypsum was added to all the treatments (except the commercial substrate) at $50 \mathrm{~g} / \mathrm{kg}$ of the base material. $\mathrm{CaCO}_{3}$ was not added to base substrates consisting of WS. While the mixture of WS + SPS were dosed with $\mathrm{CaCO}_{3}$ at $10 \mathrm{~g} / \mathrm{kg}$ of the base material, and treatments based with substrate SPS were dosed with $\mathrm{CaCO}_{3}$ at $20 \mathrm{~g} / \mathrm{kg}$ of the base material, the commercial substrates were not dosed with $\mathrm{CaCO}_{3}$ (Figure 1; Table 1). 


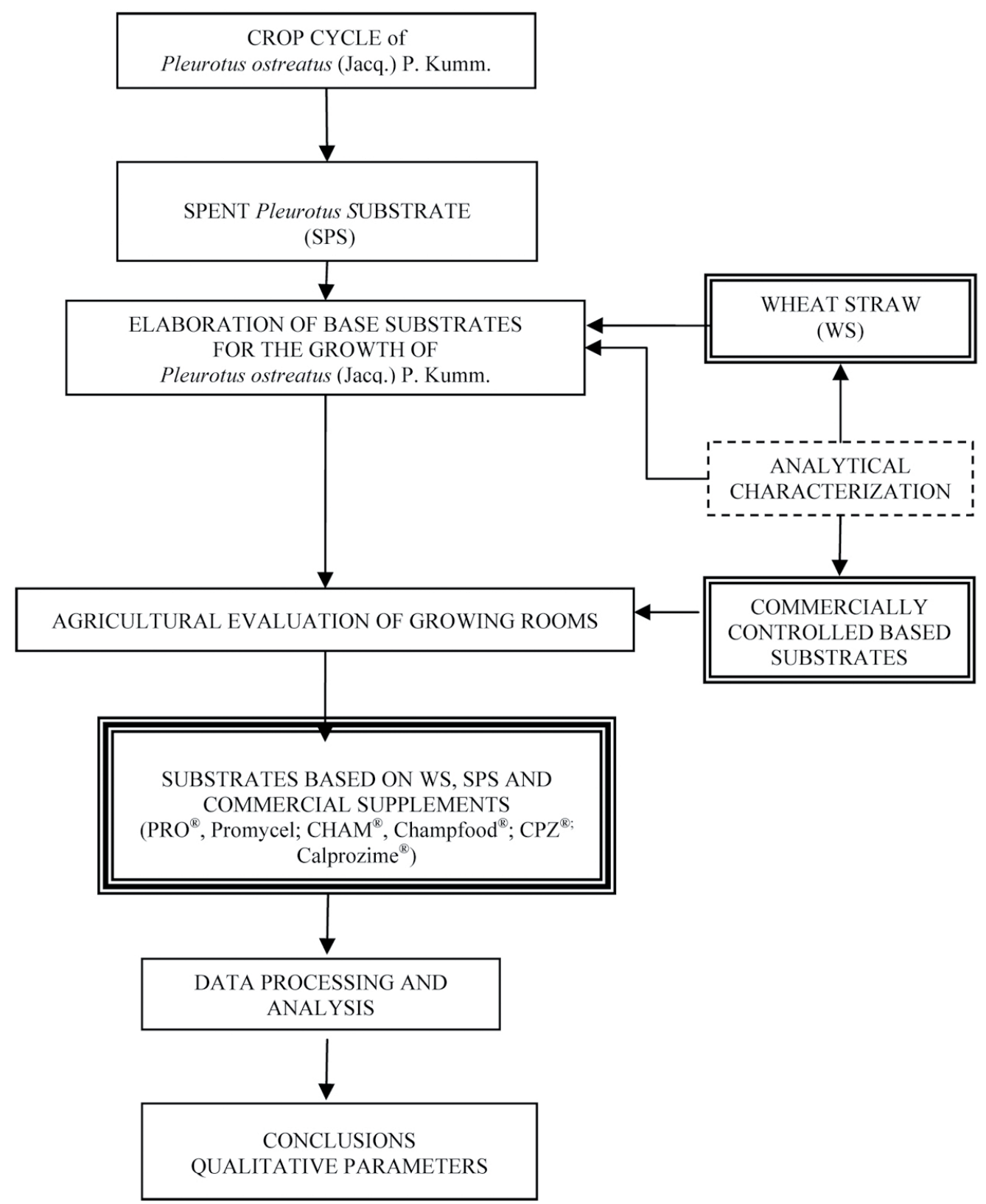

Figure 1. Schematic experiment approach. 
Table 1. Treatments tested $(\mathrm{g} / \mathrm{bag})$ in the experiment.

\begin{tabular}{cccccccc}
\hline TREATMENT & WS & SPS & PRO $^{\circledR}$ & CHAMP $^{\circledR}$ & CPZ $^{\circledR}$ & GYPSUM & CaCO $_{3}$ \\
\hline T1 & 6,000 & 0 & 0 & 0 & 0 & 300 & 0 \\
T2 & 6,000 & 0 & 120 & 0 & 0 & 300 & 0 \\
T3 & 6,000 & 0 & 0 & 120 & 0 & 300 & 0 \\
T4 & 6,000 & 0 & 0 & 0 & 120 & 300 & 0 \\
& & & & & & & \\
T5 & 3,000 & 3,000 & 0 & 0 & 0 & 300 & 60 \\
T6 & 3,000 & 3,000 & 120 & 0 & 0 & 300 & 60 \\
T7 & 3,000 & 3,000 & 0 & 120 & 0 & 300 & 60 \\
T8 & 3,000 & 3,000 & 0 & 0 & 120 & 300 & 60 \\
& & & & & & & \\
T9 & 0 & 6,000 & 0 & 0 & 0 & 300 & 120 \\
T10 & 0 & 6,000 & 120 & 0 & 0 & 300 & 120 \\
T11 & 0 & 6,000 & 0 & 120 & 0 & 300 & 120 \\
T12 & 0 & 6,000 & 0 & 0 & 120 & 300 & 120 \\
& & & & &
\end{tabular}

T, treatment; WS, wheat straw; SPS, spent Pleurotus ostreatus (Jacq.) P. Kumm. substrate; PRO $^{\circledR}$, Promycel; CHAM $^{\circledR}$, Champfood $^{\circledast}$; CPZ $^{\circledast}$, Calprozime ${ }^{\circledR}$. Amounts (g) are referred to bags of about $6.50 \mathrm{Kg}-6.00 \mathrm{Kg}$.

The first step in the preparation of the tested substrates consisted in chopping and pre-soaking the WB and subsequently mixing them with the substrates to adjust their moisture content. Then we proceeded to a pasteurizing heat treatment $\left(60{ }^{\circ} \mathrm{C}-65^{\circ} \mathrm{C}, 8 \mathrm{~h}\right)$, and a progressive decrease for at least $15 \mathrm{~h}$ to a spawning temperature $\left(25^{\circ} \mathrm{C}\right)$. Finally, supplementation and spawning were carried out (dose, $30 \mathrm{~g} / \mathrm{kg}$ of mycelium Mispaj S-44) before manual bagging in CIES (Center for Research, Experimentation and Mushroom Services) pilot plant.

All substrates were packed into transparent polythene bags of $29 \mathrm{~cm}$ in diameter and a height ranging from
25 to $35 \mathrm{~cm}$, depending on the type of substrate, approximately $6.5 \mathrm{~kg}$ of weight. These rectangular bags are made with 4 uniformly drilled holes of 2.2 $\mathrm{cm}$ in diameter distributed over the side surface of each bag.

\subsection{Driving and monitoring of the crop cycle}

The research was conducted over a 63 day cycle. The development of the crop cycle took place in an experimental greenhouse located at the CIES, located in the town of Quintanar del Rey (Cuenca, Spain) under controlled conditions 
(room temperature, substrate temperature, relative humidity, and carbon dioxide concentration) within the recommended ranges for a variety of selected mycelium and in each stage of cultivation. Incubation of the substrates lasted approximately 17 days (without external ventilation or lighting). During the incubation period, the relative humidity inside the greenhouse ranged between $92.50 \%$ and $95.50 \%$, while the substrate temperature ranged between $24.85{ }^{\circ} \mathrm{C}$ and $28.33{ }^{\circ} \mathrm{C}$, and the room temperature ranged between $20.40{ }^{\circ} \mathrm{C}$ and 23.15 ${ }^{\circ} \mathrm{C}$. After this, we proceeded to induce fruiting by ventilation (to keep $\mathrm{CO}_{2}$ levels regulated between $0.23 \%$ to $0.09 \%$ ), reduction of room temperature $\left(23.15{ }^{\circ} \mathrm{C}\right.$ to $\left.12.85{ }^{\circ} \mathrm{C}\right)$ and substrate temperature $\left(28.33{ }^{\circ} \mathrm{C}\right.$ to $\left.14.56{ }^{\circ} \mathrm{C}\right)$, and the reduction of humidity (95.50\% to $94.50 \%)$ and lighting. These values are close to the microclimatic conditions recommended by other researchers (Pardo et al., 2005b; Pardo et al., 2007; Gregori et al., 2008; Gea et al., 2009).

\subsection{Evaluation of qualitative parameters}

For the evaluation of quality parameters, on the day of the maximum harvest of the first flush, mushrooms of uniform size and maturity were used and selected on the most optimal day of the harvest period. The collection of mushrooms was performed daily in the commercial optimum stage of development, when the caps reached $3 \mathrm{~cm}$ in diameter and before they changed their shape convex to concave. Above them, the content of dry matter, crude protein and ash, texture and color were determined.

The fruit bodies surface color was measured by reflection using a Minolta brand colorimeter, model CR-300, previously calibrated with a calibration plate CR-A43 $\left(\mathrm{L}^{*}=96.12, \mathrm{a}^{*}=-0.11, \mathrm{~b}^{*}=+2.66\right)$ and illuminant D65. To evaluate the mechanical properties of mushrooms, in terms of firmness, an analyzer (TA-XT Plus of Stable Micro Systems) was used. To take this measurement, the fruit bodies were cut into small rectangular pieces (4 $\mathrm{cm}^{2}$, approximately) and were introduced into the 5-bladed Kramer Shear Cell (KS5), arranged in two adjacent uniform layers and tested at a constant speed of $2 \mathrm{~mm} / \mathrm{s}$; thus breaking strength values (Bs) were obtained, defined as the maximum force required to tear the fruit bodies (expressed in $\mathrm{N}$ ). Protein content in the carpophores was calculated by multiplying the total nitrogen content by a conversion factor of 4.38 (Delmas, 1989). Total nitrogen content was determined by the Kjeldahl method (Tecator, 1987; MAPA, 1994). To determine the ash content of the fruiting bodies, we proceeded to direct calcination of the samples at $540{ }^{\circ} \mathrm{C}$ (MAPA, 1994).

\subsection{Statistical analysis}

To carry out the statistical analysis, two software packages were used: Statgraphics ${ }^{\circledR}$ Plus version 5.1 (Statistical Graphics Corp., 2001) and SPSS ${ }^{\circledR}$ (SPSS, 2004).

Descriptive statistical techniques, principal component analysis, variance analysis and correlation and regression methods were used to evaluate the data.

Differences were considered significant for $p<0.05$.

\section{Results and Discussion}

\subsection{Analytical characterization of the base materials used and the substrates made}

The results of the different source material's chemical characteristics, substrates made, and 
commercially controlled based substrates are shown in Table 2. Prospecting mites and nematodes showed negative results for SPS tested.

In this experiment, we opted for WS because it is a universal material used in the growing of Pleurotus spp. which acts as a base material with a high prevalence of lignocellulose $\mathrm{N} \leq 1 \%$ and WS has a variable but not bullish price (Pardo et al., 2008a). If these physicochemical properties of WS are compared with the same material used in other investigations (for instance, Pardo et al., 2005a, 2005b) then we can confirm that the physicochemical values defining WS as a base material vary greatly. These variances must be considered when discussing tested results with this material or with substrates which include this base material. Thus this observed variability is due to where the WS is grown, the environmental conditions under which it develops, and the phytotechnic conditions (Varnero et al., 2010). In this experiment, we started with two base materials (WS, SPS) chosen from all other base materials in all physicochemical parameters (Table 2). SPS has higher contents of total nitrogen, total crude protein, ash contents, NFE and NDS than WS. But nevertheless, WS has a higher $\mathrm{C} / \mathrm{N}$ and organic matter, crude fat, and cellulose contents than SPS. Both substrates were enriched with supplements that, although different in their chemical composition, are characterized by high total nitrogen contents $(6.46 \%-9.16 \%)$, and consequently, high crude protein $(40.38 \%$ $57.25 \%)$ and crude fat contents $(0.96 \%-2.11 \%)$, and a low $\mathrm{C} / \mathrm{N}(\mathrm{C} / \mathrm{N}=6.00$ to $\mathrm{C} / \mathrm{N}=7.90)$, crude fiber $(5.93 \%$ to $17.41 \%)$ and cellulose contents (5.58\% to $9.95 \%)$. Also, it is noteworthy that the NDS values of $\mathrm{PRO}^{\circledR} 600, \mathrm{CHAM}^{\circledR}$ and $\mathrm{CPZ}^{\circledR}$ $(49.39 \%-72.41 \%)$ are much higher than WS (8.36 $\%)$ and SPS (26.54\%).

Commercial substrates in two types of packaging (6 $\mathrm{kg}$ and $14 \mathrm{~kg}$ bags) constitute a group with characteristics that, in most parameters, are similar to those that are characteristic of WS. When WS is supplemented with a protein product, the total nitrogen content increases, and consequently, the crude protein content and NDS values increase as well. The substrates prepared from WS are those that come closest to the commercially controlled based substrates for the $\mathrm{C} / \mathrm{N}$. This is because WS as a starting material contains very high values of this ratio $(\mathrm{C} / \mathrm{N}=95.20)$. Also, these substrates are those that have a greater value of NFE (44.87\%); this value is close to the commercial reference (41.51\%) and both crude fiber $(27.44 \%)$ and crude fat contents $(0.43 \%)$ are in the middle of the three groups of the analyzed processed substrates.

Regarding the total nitrogen content (and therefore protein), processed substrates that are closer to the optimal commercial substrate are formed by SPS, because the SPS as a starting material, has superior values in terms of nitrogen and crude protein $(1.07 \%$ and $6.69 \%$, respectively) than WS as a starting material $(0.55 \%$ and $3.44 \%)$. The substrates prepared from mixtures of WS + SPS make up the average values of the physicochemical characterization, when compared to commercial substrates. 
Table 2. Elaborate physicochemical characterization of source materials and substrates used.

\begin{tabular}{|c|c|c|c|c|c|c|c|c|c|c|c|c|c|}
\hline & & pH & Moisture & $\begin{array}{c}\text { Total } \\
\text { nitrogen }\end{array}$ & Protein & Ash & $\begin{array}{c}\text { Organic } \\
\text { matter }\end{array}$ & $\begin{array}{l}\mathrm{C} / \mathrm{N} \\
\text { ratio }\end{array}$ & $\begin{array}{l}\text { Crude } \\
\text { fiber }\end{array}$ & $\begin{array}{c}\text { Crude } \\
\text { fat }\end{array}$ & NFE & Cellulose & NDS \\
\hline \multirow{5}{*}{$\begin{array}{c}\text { BASE } \\
\text { MATERIALS }\end{array}$} & WS & 7.85 & 728 & 5.50 & 34.40 & 97.70 & 902.30 & 95.20 & 411.90 & 5.20 & 450.80 & 409.10 & 83.60 \\
\hline & SPS & 7.13 & 758 & 10.70 & 66.90 & 202.50 & 797.50 & 43.20 & 253.80 & 3.80 & 473.00 & 272.10 & 265.40 \\
\hline & PRO $^{\otimes}$ & 6.11 & 128 & 91.60 & 572.50 & 55.00 & 945.00 & 6.00 & 59.30 & 21.10 & 292.10 & 55.80 & 724.10 \\
\hline & CHAM $^{\otimes}$ & 5.91 & 134 & 79.20 & 495.00 & 63.30 & 936.70 & 6.90 & 60.70 & 9.60 & 371.40 & 57.80 & 696.40 \\
\hline & $\mathrm{CPZ}^{\circledast}$ & 9.46 & 110 & 64.60 & 403.80 & 118.00 & 882.00 & 7.90 & 174.10 & 13.70 & 290.50 & 99.50 & 493.90 \\
\hline \multirow{5}{*}{$\begin{array}{c}\text { SUBSTRATES } \\
\text { MADE }\end{array}$} & $\begin{array}{l}\text { T1 } \\
\text { T2 } \\
\text { T3 } \\
\text { T4 }\end{array}$ & 7.46 & 697 & 5.7 & 35.6 & 237.00 & 763.0 & 77.6 & 274.4 & 4.3 & 448.7 & 327.3 & 86.6 \\
\hline & $\begin{array}{l}\text { T5 } \\
\text { T6 } \\
\text { T7 } \\
\text { T8 }\end{array}$ & 7.84 & 707 & 6.4 & 40.0 & 283.2 & 716.8 & 65.0 & 320.0 & 3.6 & 353.2 & 291.1 & 125.3 \\
\hline & $\begin{array}{c}\text { T9 } \\
\text { T10 } \\
\text { T11 } \\
\text { T12 }\end{array}$ & 7.53 & 730 & 7.6 & 47.5 & 401.8 & 598.2 & 45.7 & 234.9 & 5.6 & 310.2 & 210.0 & 180.0 \\
\hline & $\begin{array}{l}\text { T13 } \\
\text { T14 } \\
\end{array}$ & 8.00 & 703 & 7.4 & 46.3 & 99.0 & 901.0 & 70.6 & 436.0 & 3.7 & 415.1 & 396.4 & 196.5 \\
\hline & $\begin{array}{l}\text { Average } \\
\text { CV (\%) }\end{array}$ & \begin{tabular}{|l|}
7.71 \\
3.32
\end{tabular} & $\begin{array}{c}709.25 \\
2.03\end{array}$ & $\begin{array}{c}6.8 \\
13.10\end{array}$ & $\begin{array}{l}42.3 \\
13.2\end{array}$ & $\begin{array}{c}255.2 \\
49.0\end{array}$ & $\begin{array}{c}744.7 \\
16.8\end{array}$ & $\begin{array}{l}64.7 \\
21.1\end{array}$ & $\begin{array}{c}316.3 \\
27.5\end{array}$ & $\begin{array}{c}4.3 \\
21.4\end{array}$ & $\begin{array}{c}381.8 \\
16.2\end{array}$ & $\begin{array}{c}306.2 \\
25.3\end{array}$ & $\begin{array}{l}147.1 \\
34.3\end{array}$ \\
\hline
\end{tabular}

T, treatment; WS, wheat straw; SPS, spent Pleurotus ostreatus (Jacq,) P, Kumm, substrate; PRO $^{\circledR}$, Promycel; CHAM $^{\circledast}$,

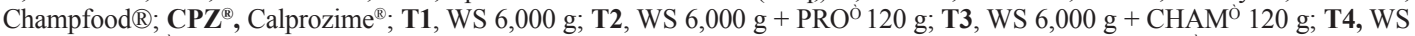
6,000 g + CPZ $120 \mathrm{~g}$; T5, WS 3,000 g + SPS 3,000 g + CaCO $60 \mathrm{~g}$; T6, WS 3,000 g + SPS 3,000 g + PRO $120 \mathrm{~g}+\mathrm{CaCO}_{3} 54$ $\mathrm{g}$; T7, WS $3,000 \mathrm{~g}+$ SPS $3,000 \mathrm{~g}+$ CHAM $^{\dot{0}} 120 \mathrm{~g}+\mathrm{CaCO}_{3} 48 \mathrm{~g}$; T8, WS 3,000 g + SPS 3,000 g + CPZ $120 \mathrm{~g}+\mathrm{CaCO}_{3} 42 \mathrm{~g}$; T9, SPS 6,000 g + $\mathrm{CaCO}_{3} 120 \mathrm{~g}$; T10, SPS $6,000 \mathrm{~g}+\mathrm{PRO}^{\dot{o}} 120 \mathrm{~g}+\mathrm{CaCO}_{3} 108 \mathrm{~g}$; T11, SPS 6,000 g + CHAM ${ }^{\grave{j}} 120 \mathrm{~g}+\mathrm{CaCO}_{3} 96$ g; T12, SPS 6,000 g + CPZ $120 \mathrm{~g}+\mathrm{CaCO}_{3} 84 \mathrm{~g}$; T13, commercially controlled based substrates (bag $6 \mathrm{~kg}$ ); T14, commercially controlled based substrates (sack commercial format, $14.78 \mathrm{~kg}$ ). CV, coefficient of variation; NFE, nitrogen free extractives; NDS, neutral detergent-soluble. Results expressed in $\mathbf{g} / \mathbf{k g}$ dry matter, except $\mathrm{pH}$, moisture (fresh matter) and $\mathrm{C} / \mathrm{N}$ ratio.

\subsection{Qualitative production parameters. Descriptive statistics and ANOVA}

In Table 3, the descriptive statistics of crude protein and ash contents, as well as brightness values $\left(\mathrm{L}^{*}\right)$, red-green $\left(\mathrm{a}^{*}\right)$ and yellow-blue $\left(\mathrm{b}^{*}\right)$ chromaticity, $\mathrm{Bs}$, and $\mathrm{C}_{\mathrm{E}}$ in the harvested mushrooms are shown.

Overall, proteins are the most critical components that contribute to the nutritional value of a food, and fungi, are a good source of them. Organic supplements such as soybean meal, alfalfa, and cottonseed powder and meal, not only increase yields, but also the mushrooms protein content (Zadrazil, 1980a, 1980b). Most of the interest in the nutritional value of mushrooms is related to the nutritional quantity and quality of proteins. The mushrooms protein content values achieved in this experiment ranged between $16.51 \%$ (T9) and $19.49 \%$ (T5) (Table 3), which are much lower than the values given by Rodriguez Barreal (1987) and Benavides and Herrera (2009), who offered an average composition of $30 \%$ to $34 \%$ of its crude protein content in mushrooms of $P$. ostreatus. Other researchers (Mandeel et al., 2005), obtained protein content ranging between $17.80 \%$ and $23.30 \%$ in P. ostreatus and $30 \%$ in P. sajor-caju.

According Kachlisvili et al. (2005), the nutritional value in the production of edible mushrooms is maintained by using different base substrates and mixtures thereof. Same conclusions were obtained in this experiment, whose results showed no significant difference between the different tested treatments. In other research carried out in Castilla - La Mancha, Pardo et al. (2005a) achieved crude protein content 
ranging between $14.04 \%$ and $17.75 \%$, depending on the tested substrate, the type of substrate treatment, and mycelium used. Depending on the type of tested substrate and substrate treatment, Pardo et al. (2007), reached higher values in the fruit bodies protein content (between 19.07\% and 23.98\%). Also, Pardo et al. (2008b) working with $P$. ostreatus obtained a wide range of mushroom protein content values (between $14.00 \%$ and $26.30 \%$ ), depending on the type of substrate, substrate treatment, and the weight of the contents of the bag used.
Recently, higher values than those obtained in this experiment have been confirmed in P. ostreatus, by Forero et al. (2008), using pepper residues as substrates (between $15.60 \%$ and $28.60 \%$ ) and by Fonseca et al. (2009) reaching protein content of $30.52 \%$. Slightly higher values were obtained in an experiment carried by Siwulski et al. (2009), whose values ranged between $17.30 \%$ and $21.10 \%$, which were dependent on the amount of Ginkgo biloba L. leaves added but not its botanical species.

Table 3. ANOVA of the qualitative parameters of the Experiment.

\begin{tabular}{|c|c|c|c|c|c|c|c|}
\hline \multirow[b]{2}{*}{ Substrate } & \multirow{2}{*}{$\begin{array}{c}\text { Crude } \\
\text { protein } \\
(\mathrm{g} / 100 \mathrm{~g})\end{array}$} & \multirow{2}{*}{$\begin{array}{c}\text { Ash } \\
\text { contents } \\
(\mathrm{g} / \mathbf{1 0 0} \mathrm{g})\end{array}$} & \multicolumn{3}{|c|}{ Color } & \multirow{2}{*}{$\begin{array}{c}\mathbf{B}_{\mathrm{s}} \\
(\mathrm{N})\end{array}$} & \multirow{2}{*}{$\begin{array}{c}\mathrm{C}_{\mathrm{E}} \\
(\mathrm{mJ})\end{array}$} \\
\hline & & & $\mathbf{L}^{*}$ & $a^{*}$ & $\mathbf{b}^{*}$ & & \\
\hline T1* & 18.77 & 7.04ab & 73.25 & $2.17 \mathrm{~b}$ & $11.04 \mathrm{~d}$ & 258.60 & $1,000.73$ \\
\hline $\mathbf{T} 2^{*}$ & 19.43 & 6.49abc & 71.24 & $2.51 \mathrm{ab}$ & $11.75 \mathrm{bcd}$ & 250.62 & $1,041.90$ \\
\hline $\mathrm{T3}^{*}$ & 18.00 & $6.15 b c$ & 73.81 & $2.16 \mathrm{~b}$ & $12.07 \mathrm{bcd}$ & 281.68 & $1,123.07$ \\
\hline $\mathrm{T} 4^{*}$ & 17.46 & $6.28 \mathrm{abc}$ & 72.91 & $2.26 \mathrm{~b}$ & $11.53 \mathrm{~cd}$ & 253.13 & 978.50 \\
\hline T5* & 19.49 & $6.77 \mathrm{abc}$ & 73.73 & $2.36 \mathrm{ab}$ & $11.78 \mathrm{bcd}$ & 271.87 & $1,105.12$ \\
\hline T6" & 17.02 & $5.81 \mathrm{c}$ & 71.52 & $2.61 \mathrm{ab}$ & $12.33 \mathrm{bcd}$ & 235.07 & $1,021.38$ \\
\hline $\mathbf{T} 7^{*}$ & 19.08 & $6.00 \mathrm{c}$ & 71.27 & $2.48 \mathrm{ab}$ & $12.15 \mathrm{bcd}$ & 265.20 & $1,065.58$ \\
\hline T8* & 17.68 & $5.99 \mathrm{c}$ & 73.31 & $2.53 \mathrm{ab}$ & 12.76abcd & 256.87 & 948.55 \\
\hline $\mathrm{T9}^{*}$ & 16.51 & $6.16 \mathrm{bc}$ & 72.52 & $2.46 \mathrm{ab}$ & $12.12 \mathrm{bcd}$ & 260.68 & $1,034.40$ \\
\hline T10* & 17.26 & $6.29 \mathrm{abc}$ & 72.72 & $2.55 \mathrm{ab}$ & $13.17 \mathrm{abc}$ & 249.63 & $1,037.28$ \\
\hline T11* & 16.94 & $6.24 a b c$ & 71.46 & $3.09 \mathrm{a}$ & $14.43 \mathrm{a}$ & 225.13 & 997.02 \\
\hline T12* & 17.99 & $5.97 \mathrm{c}$ & 73.99 & $2.44 a b$ & $13.52 \mathrm{ab}$ & 219.08 & 972.95 \\
\hline T13* & 18.14 & $7.05 \mathrm{ab}$ & 70.69 & $2.55 \mathrm{ab}$ & $12.07 \mathrm{bcd}$ & 288.00 & $1,139.90$ \\
\hline T14* & 18.75 & $7.21 \mathrm{a}$ & 69.12 & $2.62 \mathrm{ab}$ & $12.44 \mathrm{bcd}$ & 238.90 & 937.73 \\
\hline Average ${ }^{* * *}$ & 18.04 & 6.39 & 72.25 & 2.48 & 12.37 & 253.89 & $1,028.87$ \\
\hline Fisher F & 1.73 & 5.24 & 1.32 & 1.89 & 5.10 & 1.54 & 0.64 \\
\hline $\mathbf{S}_{\mathbf{L}}$ & $0.07^{\mathrm{ns}}$ & $0.00^{* * *}$ & $0.23^{\mathrm{ns}}$ & $0.05^{*}$ & $0.00^{* *}$ & $0.12^{\mathrm{ns}}$ & $0.82^{\mathrm{ns}}$ \\
\hline
\end{tabular}


T, treatment; WS, wheat straw; SPS, spent Pleurotus ostreatus (Jacq.) P. Kumm. substrate; PRO ${ }^{\circledR}$, Promycel; CHAM $^{\circledR}$,

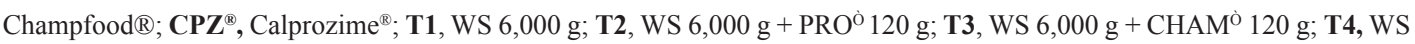
6,000 g + CPZ $120 \mathrm{~g}$; T5, WS 3,000 g + SPS 3,000 g + CaCO $60 \mathrm{~g}$; T6, WS 3,000 g + SPS 3,000 g + PRO $120 \mathrm{~g}+\mathrm{CaCO}_{3}$ $54 \mathrm{~g}$; T7, WS 3,000 g + SPS 3,000 g + $\mathrm{CHAM}^{\dot{0}} 120 \mathrm{~g}+\mathrm{CaCO}_{3} 48 \mathrm{~g}$; T8, WS 3,000 g + SPS 3,000 g + CPZ $120 \mathrm{~g}+\mathrm{CaCO}_{3}$ $42 \mathrm{~g}$; T9, SPS 6,000 g + $\mathrm{CaCO}_{3} 120 \mathrm{~g}$; T10, SPS 6,000 g + PRO $120 \mathrm{~g}+\mathrm{CaCO}_{3} 108 \mathrm{~g}$; T11, SPS 6,000 g + CHAM $120 \mathrm{~g}+$ $\mathrm{CaCO}_{3} 96 \mathrm{~g}$; T12, SPS 6,000 g + CPZ $120 \mathrm{~g}+\mathrm{CaCO}_{3} 84 \mathrm{~g}$; T13, commercially controlled based substrates (bag $6 \mathrm{~kg}$ ); T14, commercially controlled based substrates (sack commercial format, $14.78 \mathrm{~kg}$ ). $\mathbf{L}^{*}$, brightness; $\mathbf{a}^{*}$, red-green color components; $\mathbf{b}^{*}$, yellow-blue color components; $\mathbf{B}_{\mathrm{S}}$, breaking strength; $\mathbf{C}_{\mathbf{E}}$, compression energy, $\mathbf{S}_{\mathrm{L}}, \mathbf{F}$ significance level Fisher.

ns, no significant difference, $\mathrm{p}>0.05$; ${ }^{*} \mathrm{P}$-value $<0.05$; ${ }^{*} \mathrm{P}$-value $<0.01$; *** $\mathrm{P}$-value $<0.001$. For each column, values followed by different letters are significantly different from each other $(\mathrm{p}=0.05$, Tukey-HSD).

* Mean values for each treatment were obtained using 6 replicates.

** The values were obtained with 84 repetitions (14 treatments).

Lower values for protein content than those obtained in this experiment were achieved by Oyetayo and Akindahunsi (2004) working with P. sajor-caju, comparing the protein content of mushrooms grown in substrates of grated cobs $(17.49 \%)$ and without supplementation (14.94\%). In the same species, but with higher values for protein content, Hassan et al. (2010) obtained: sawdust $(22.17 \%)$, soybean straw (24.08\%), sugar cane bagasse $(21.33 \%)$ and rice straw $(22.75 \%)$.

The mushrooms ash content obtained in this experiment ranged between 5.81\% (T6) and 7.04\% (T1) (Table 3). Similar values to this experiment were obtained by Manzi et al. (1999) (between 6.70\% and $15.40 \%)$, by Rodriguez Barreal (1987) (7.50\%) and Benavides and Herrera (2009) (5.55\%). Siwulski et al. (2009), also working with oyster mushroom, but with alder sawdust substrates supplemented with leaves of two different species of Ginkgo biloba L., concluded that the addition of G. biloba L. leaves does not affect the ash content of fruiting bodies: green leaves, between $6.90 \%$ (no leaves and containing $10 \%$ leaves) and $7.00 \%$ (containing $1 \%$ leaves); and yellow leaves, between $6.80 \%$ (no leaves) and $7.20 \%$ (containing 10\% leaves).

Pardo et al. (2005a), on research carried out in Castilla La Mancha with $P$. ostreatus, obtained slightly higher ash content values in mushrooms than in this experiment, depending on the type of substrate, treatment, and mycelium used (from $6.83 \%$ to $7.70 \%$ ). Values similar to those provided by this experiment are also offered by Pardo et al. (2007) (also with the oyster mushroom) between $6.00 \%$ and $7.14 \%$ depending on the type of substrate and treatment used. Pardo et al. (2008b) also with P. ostreatus, obtained different values for ash content, depending on the type of substrate, treatment, and weight of the bag used, between $5.80 \%$ and $7.50 \%$ ranging (also similar to those achieved in this experiment). While these authors observed no differences in dry matter and ash content of the fruiting bodies obtained in different combinations, they found lower protein content in the mushrooms of the most productive combinations.

Forero et al. (2008), working with P. ostreatus and pepper waste obtained ash content ranging between $8.81 \%$ and $9.84 \%$ (values higher than those obtained in this experiment) which the researchers attribute to the pepper waste's high ash content. Fonseca et al. (2009), using a mixture of rice straw (35\%), Juncus effusus L. (25\%) and rice bran (40\%), obtained $6.38 \%$ of crude protein content in the fruiting bodies of $P$. ostreatus. In other Pleurotus species, such as P. eryngii, Manzi et al. (1999) obtained, on substrates based on WS + sugar beet (15\%) ash content ranging between $6.90 \%$ and $10.50 \%$. 
Also, in P. eryngii, Hassan et al. (2010) obtained different ash contents in different substrates: sawdust (6.94\%), soybean straw (7.66\%), sugar cane bagasse $(6.54 \%)$ and rice straw $(8.02 \%)$. In another species, P. sajor-caju, Oyetayo and Akindahunsi (2004) compared the ash content of cultivated mushrooms in grated ears substrate (10.51\%) and without supplementation (7.41\%).

With regard to color, lightness $\left(\mathrm{L}^{*}\right)$ ranged between 71.24 (T2) and 73.99 (T12) (Table 3). These values are similar to those achieved by Rodriguez Estrada et al. (2009), who investigated P. eryngii mushrooms grown on substrates made of straw, and achieved brightness values in mushrooms ranging from 54.70 (substrate covered by a casing soil) to 74.10 (substrate not covered).

The red-green color component $\left(\mathrm{a}^{*}\right)$ of mushrooms varies between 2.16 (T3) and 3.09 (T11) and the yellowblue component $\left(\mathrm{b}^{*}\right)$ varies between 11,04 (T1) and 14.43 (T11) (Table 3).

Bs values (the first component of texture) obtained in this experiment ranged from $219.08 \mathrm{~N}$ (T12) and $281.68 \mathrm{~N}$ (T3) (Table 3). The second component of texture, $\mathrm{C}_{\mathrm{E}}$, was obtained at a range between $948.55 \mathrm{~mJ}$ (T8) and $1123.07 \mathrm{~mJ}$ (T3) (Table 3) in this experiment. Texture (hardness, cohesiveness, springiness, and chewiness) was controlled in Pleurotus spp. cultivated on rice straw. According to these authors, the increase in hardness and chewiness, and the decrease in cohesion and elasticity in these mushrooms can be attributed to the loss of moisture in the mushroom bodies.

\subsection{Correlation matrix and "step by step" regression models}

Table 4 presents the correlation matrix between qualitative production parameters and physicochemical properties of the substrates prepared in this experiment. The qualitative parameters that showed significant correlations were red-green $\left(a^{*}\right)$ and yellow-blue $\left(b^{*}\right)$ chromaticity. These were positively correlated with total nitrogen content, crude fat, and neutral detergent-soluble, and negatively correlated, with cellulose and lignin contents and nitrogen free extractives and $\mathrm{C} / \mathrm{N}$ ratio.

Table 5 presents the correlation matrix between production and qualitative parameters, GI, the earliness, and quantitative production parameters. Only the blue color component $\left(b^{*}\right)$ color is significantly and positively correlated with the days between inoculation and induction of early primordia. From the viewpoint of statistics, Bs, in addition to being positively correlated with the $\mathrm{C}_{\mathrm{E}}$, is negatively correlated with the red-green $\left(\mathrm{a}^{*}\right)$ and yellow-blue $\left(b^{*}\right)$ color components of the mushrooms (Table 6). The lightness $\left(\mathrm{L}^{*}\right)$ was negatively correlated only with red-green $\left(a^{*}\right)$ chromaticity of the mushrooms. Finally, this component also negatively correlated with the Bs and lightness $\left(\mathrm{L}^{*}\right)$, and positively with the yellow-blue (b*) chromaticity (Table 6).

Table 7 presents the "step by step" regression models for qualitative production parameters depending on the physicochemical properties of the substrates, GI, earliness and production characteristics of the quantitative parameters. In general, few models, obtained by "step by step" regression, have been established that include all of the qualitative production parameters (dependent variables) and physicochemical characteristics substrates, GI, precocity, quantitative and qualitative production parameters (independent variables), being that in most cases they are low corresponding determination coefficients. Of the significant models which explain the greater variability of the Bs, yellow-blue ( $\left.b^{*}\right)$ chromaticity (negative coefficient) and $\mathrm{C}_{\mathrm{E}}$ (positive coefficient) are included as independent variables reaching a value $\mathrm{R}^{2}$ $=61,00 \%$. The $\mathrm{C}_{\mathrm{E}}$ variability is explained by a simple linear model that includes Bs (positive coefficient) as an independent variable with a very low goodness of fit $\left(\mathrm{R}^{2}=38.30 \%\right)$. The variability in lightness $\left(\mathrm{L}^{*}\right)$ and 
the two color components of the harvested mushrooms (red-green $\left(\mathrm{a}^{*}\right)$ and yellow-blue $\left(\mathrm{b}^{*}\right)$ ) is best explained by models that include not only one or two of the other characteristics that define the color, but also includes the dry matter content and the variability of yellow-blue $\left(b^{*}\right)$ chromaticity as an independent variable.

\section{Conclusions}

The combination of WS (3,000 g) and SPS $(3,000$ g) supplemented with $120 \mathrm{~g}$ each of the tested commercial supplements (Promycel ${ }^{\circledR}$, Calprozime ${ }^{\circledR}$, and Champfood ${ }^{\mathbb{}}$ ) are substrates that favor lightness $\left(\mathrm{L}^{*}\right)$, and red-green $\left(\mathrm{a}^{*}\right)$ and yellow-blue $\left(\mathrm{b}^{*}\right)$ color components in harvested mushrooms. Consequently, these compost formulations based on degraded Pleurotus ostreatus could be a low cost substrate, with selective and balanced in nutrients for the growth and development of oyster mushrooms.

Table 4. Correlation matrix between production of quantitative parameters and physicochemical characteristics of the substrates.

\begin{tabular}{cccccccc} 
& $\begin{array}{cccccccc}\text { Crude } \\
\text { protein }\end{array}$ & $\begin{array}{c}\text { Ash } \\
\text { contents }\end{array}$ & $\begin{array}{c}\mathbf{B}_{\mathbf{s}} \\
(\mathbf{N})\end{array}$ & $\begin{array}{c}\mathbf{C}_{\mathbf{E}} \\
(\mathbf{m J})\end{array}$ & $\mathbf{L}^{*}$ & $\mathbf{a}^{*}$ & $\mathbf{b}^{*}$ \\
& $\mathbf{g} / \mathbf{1 0 0} \mathbf{g})$ & $(\mathbf{g} / \mathbf{1 0 0} \mathbf{g})$ & & & & & \\
\hline \multirow{2}{*}{$\mathbf{p H}$} & 0.160 & -0.322 & 0.107 & 0.074 & -0.140 & 0.188 & 0.032 \\
& $(0.619)$ & $(0.307)$ & $(0.742)$ & $(0.819)$ & $(0.663)$ & $(0.559)$ & $(0.922)$ \\
Nitrogen $_{\mathbf{T}}{ }^{1}$ & -0.555 & -0.349 & -0.545 & -0.223 & -0.033 & $0.608^{*}$ & $0.782^{* *}$ \\
& $(0.061)$ & $(0.266)$ & $(0.067)$ & $(0.486)$ & $(0.919)$ & $(0.036)$ & $(0.003)$ \\
C/N ratio $^{*}$ & 0.549 & 0.359 & 0.541 & 0.220 & 0.037 & $-0.613^{*}$ & $-0.782^{* *}$ \\
& $(0.064)$ & $(0.252)$ & $(0.069)$ & $(0.491)$ & $(0.909)$ & $(0.034)$ & $(0.003)$ \\
Crude fiber $^{1}$ & 0.468 & -0.047 & 0.419 & 0.196 & -0.093 & -0.220 & -0.451 \\
& $(0.125)$ & $(0.886)$ & $(0.176)$ & $(0.542)$ & $(0.773)$ & $(0.493)$ & $(0.141)$ \\
Crude fat $^{1}$ & -0.530 & -0.053 & -0.487 & -0.220 & 0.068 & 0.340 & $0.576^{*}$ \\
& $(0.076)$ & $(0.869)$ & $(0.108)$ & $(0.493)$ & $(0.834)$ & $(0.280)$ & $(0.050)$ \\
NFE $^{1}$ & 0.456 & 0.438 & 0.466 & 0.180 & 0.081 & $-0.630^{*}$ & $-0.735^{* *}$ \\
& $(0.136)$ & $(0.154)$ & $(0.127)$ & $(0.576)$ & $(0.803)$ & $(0.028)$ & $(0.006)$ \\
Cellulose $^{1}$ & 0.565 & 0.328 & 0.552 & 0.228 & 0.024 & $-0.595^{*}$ & $-0.779^{* *}$ \\
& $(0.055)$ & $(0.299)$ & $(0.063)$ & $(0.477)$ & $(0.942)$ & $(0.041)$ & $(0.003)$ \\
NDS $^{1}$ & -0.545 & -0.365 & -0.538 & -0.218 & -0.040 & $0.616^{*}$ & $0.782^{* *}$ \\
& $(0.067)$ & $(0.243)$ & $(0.071)$ & $(0.495)$ & $(0.901)$ & $(0.033)$ & $(0.003)$ \\
\hline
\end{tabular}

$\mathbf{B}_{\mathrm{S}}$, breaking strength; $\mathbf{C}_{\mathrm{E}}$, compression energy; $\mathbf{L}^{*}$, brightness; $\mathbf{a}^{*}$, red-green color components; $\mathbf{b}^{*}$, yellow-blue color components; Nitrogen ${ }_{\mathrm{T}}$ total nitrogen; NFE, nitrogen free extractives; NDS, neutral detergent-soluble; ${ }^{1}, \mathbf{g} / \mathbf{k g}$ dry matter.

Results in parentheses indicate statistical significance. No significant ( $\mathrm{p}>0.05)$ (non *); significant at $95 \%(0.01<\mathrm{p} \leq 0.05)(*)$; significant at $99 \%(0.001<\mathrm{p} \leq 0.01)(* *)$. 
Table 5. Correlation matrix between production of qualitative parameters and the rate of germination, earliness, and production of quantitative parameters.

\begin{tabular}{cccccccc}
\cline { 2 - 8 } & $\begin{array}{c}\text { Crude } \\
\text { protein } \\
(\mathbf{g} / \mathbf{1 0 0} \mathbf{g})\end{array}$ & $\begin{array}{c}\text { Ash } \\
\text { contents } \\
(\mathbf{g} / \mathbf{1 0 0} \mathbf{g})\end{array}$ & $\begin{array}{c}\mathbf{B}_{\mathbf{s}} \\
(\mathbf{N})\end{array}$ & $\begin{array}{c}\mathbf{C}_{\mathbf{E}} \\
(\mathbf{m J} \mathbf{J})\end{array}$ & $\mathbf{L}^{*}$ & $\mathbf{a}^{*}$ & $\mathbf{b}^{*}$ \\
\hline Germination & 0.454 & 0.094 & -0.144 & -0.043 & 0.038 & 0.011 & 0.089 \\
Index & $(0.138)$ & $(0.770)$ & $(0.655)$ & $(0.894)$ & $(0.907)$ & $(0.974)$ & $(0.782)$ \\
$\mathbf{1}^{\text {rs }}$ Flush & -0.560 & -0.095 & -0.322 & 0.031 & -0.096 & 0.517 & $0.619^{*}$ \\
spawning & $(0.058)$ & $(0.768)$ & $(0.307)$ & $(0.924)$ & $(0.766)$ & $(0.085)$ & $(0.032)$ \\
Total & -0.395 & -0.196 & -0.155 & 0.062 & -0.274 & 0.529 & 0.501 \\
spawning & $(0.204)$ & $(0.541)$ & $(0.630)$ & $(0.849)$ & $(0.390)$ & $(0.077)$ & $(0.097)$ \\
Total & 0.420 & 0.134 & 0.376 & 0.043 & -0.102 & -0.412 & -0.571 \\
quantity of & $(0.174)$ & $(0.678)$ & $(0.229)$ & $(0.894)$ & $(0.753)$ & $(0.183)$ & $(0.053)$ \\
mushrooms & & & & & & & \\
BE & 0.352 & 0.033 & 0.318 & 0.061 & -0.107 & -0.409 & -0.504 \\
& $(0.261)$ & $(0.918)$ & $(0.314)$ & $(0.850)$ & $(0.741)$ & $(0.186)$ & $(0.095)$ \\
\hline
\end{tabular}

$\mathbf{B}_{\mathrm{s}}$, breaking strength; $\mathbf{C}_{\mathbf{E}}$, compression energy; L*, brightness; $\mathbf{a}^{*}$, red-green color components; $\mathbf{b}^{*}$, yellow-blue color components; BE, biological efficiency ( $\mathrm{kg} / 100 \mathrm{~kg}$ of dry substrate).

Results in parentheses indicate statistical significance. No significant ( $\mathrm{p}>0.05)$ (non *); significant at 95\% (0.01 $<\mathrm{p} \leq 0.05)(*)$.

Table 6. Correlation matrix between production of qualitative parameters.

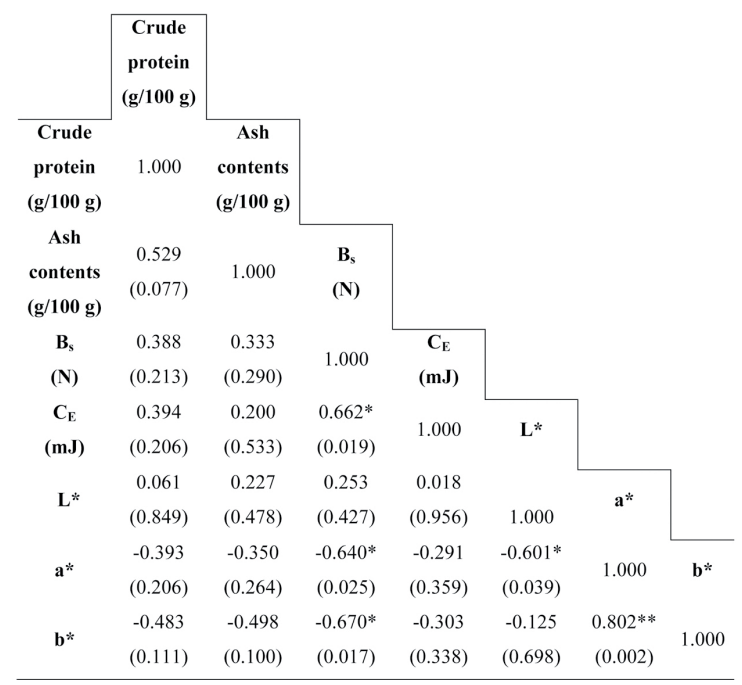

$\mathbf{B}_{\mathrm{s}}$, breaking strength; $\mathbf{C}_{\mathrm{E}}$, compression energy; $\mathbf{L}^{*}$, brightness; $\mathbf{a}^{*}$, red-green color components; $\mathbf{b}^{*}$, yellow-blue color components; BE, biological efficiency $(\mathrm{kg} / 100 \mathrm{~kg}$ of dry substrate).

Results in parentheses indicate statistical significance. No significant ( $p>0.05)$ (no *); significant at $95 \%(0.01<\mathrm{p} \leq 0.05)(*)$; significant at $99 \%(0.001<\mathrm{p} \leq 0.01)(* *)$. 
Table 7. Models obtained by regressing "step by step".

\begin{tabular}{|c|c|c|c|c|}
\hline $\begin{array}{r}\text { Explained } \\
\text { variable }\end{array}$ & $\begin{array}{c}\text { Independent } \\
\text { variable }\end{array}$ & Equation & $\begin{array}{c}\mathrm{R}^{2} \\
\text { corrected }\end{array}$ & SE \\
\hline $\mathbf{B}_{\mathrm{s}}$ & $\begin{array}{c}\mathrm{PCC}+\mathrm{QPP}+ \\
\mathrm{CPP}\end{array}$ & $\begin{array}{c}\mathrm{B}_{\mathrm{S}}=195.142 *-10.039 * \cdot \mathrm{b}^{*}+ \\
0.177 * \cdot \mathrm{C}_{\mathrm{E}}\end{array}$ & $61.00 * *$ & 11.44484 \\
\hline $\mathrm{C}_{\mathrm{E}}$ & $\begin{array}{c}\mathrm{PCC}+\mathrm{QPP}+ \\
\mathrm{CPP}\end{array}$ & $\mathrm{C}_{\mathrm{E}}=548.857^{* *}+1.896^{*} \cdot \mathrm{B}_{\mathrm{S}}$ & $38.30 *$ & 41.20304 \\
\hline $\mathbf{L}$ & $\begin{array}{c}\mathrm{PCC}+\mathrm{QPP}+ \\
\mathrm{CPP}\end{array}$ & $\begin{array}{c}\mathrm{L}^{*}=73.685^{* * *}-5.920^{* * *} \cdot \mathrm{a}^{*}+ \\
1.096^{* *} \cdot \mathrm{b}^{*}\end{array}$ & $65.30 * *$ & 0.60953 \\
\hline$a^{*}$ & $\begin{array}{c}\mathrm{PCC}+\mathrm{QPP}+ \\
\mathrm{CPP}\end{array}$ & $\begin{array}{c}\mathrm{a}^{*}=8.825^{* * *}+0.192 * * * \cdot \mathrm{b}^{*}- \\
0.120^{* * *} \cdot \mathrm{L}^{*}\end{array}$ & $87.40 * * *$ & 0.34014 \\
\hline$b^{*}$ & $\mathrm{PCC}+\mathrm{CPP}$ & $\begin{array}{c}\mathrm{b}^{*}=4.849^{* * *}+0.386^{* * *} \cdot \mathrm{DM}+ \\
1.425^{*} \cdot \mathrm{a}^{*}\end{array}$ & $87.00 * * *$ & 0.34014 \\
\hline
\end{tabular}

$\mathbf{R}^{2}$, determination coefficient (\%); $\mathbf{S E}$, standard error of the estimate.

PHYSICO-CHEMICAL CHARACTERISTICS OF SUBSTRATE (PCC): pH (aq. 1:5, w/w), total nitrogen (g/kg, odm), ash (g/kg, odm), C/N ratio, crude fiber (CFi; g/kg, odm), crude fat (CFa; g/kg, odm), nitrogen free extractives (NFE; g/kg, odm), cellulose ( $\mathrm{g} / \mathrm{kg}$, odm), neutral-detergent soluble (NDS; $\mathrm{g} / \mathrm{kg}$, odm), odm, on dry matter.

INDEX GERMINATION, EARLINESS AND QUANTITATIVE PRODUCTION PARAMETERS (QPP): germination index (GI), days from inoculation to the formation of the first primordia (P2), days from inoculation to the onset of harvest (P4), $\mathrm{n}^{\mathrm{o}}$ mushrooms (quantity of mushrooms), biological efficiency (BE, $\mathrm{kg} / 100 \mathrm{~kg}$ of dry substrate).

QUALITATIVE PRODUCTION PARAMETERS (CPP): average unit weight of uncut mushrooms (g), dry matter (DM, $\mathrm{g} / 100 \mathrm{~g}$ ), crude protein $(\mathrm{g} / 100 \mathrm{~g})$, ash contents $(\mathrm{g} / 100 \mathrm{~g}), \mathbf{B}_{\mathbf{s}}$, breaking strength; $\mathbf{C}_{\mathbf{E}}$, compression energy; $\mathbf{L}^{*}$, brightness; $\mathbf{a}^{*}$, red-green color components; $\mathbf{b} *$, yellow-blue color components.

Significant at $95 \%(0.01<\mathrm{p} \leq 0.05)(*)$; significant at $99 \%(0.001<\mathrm{p} \leq 0.01)(* *) ; 99.9 \%$ significant $(\mathrm{p} \leq 0.001)(* * *)$. Regressions include only those whose coefficients that accompany the independent variables are significant, provided that the significance of the model also is. 


\section{References}

ANKOM. 2005. Method for Determining Acid Detergent Lignin in Beakers. ANKOM Technology Method AK 8/05. Macedon, NY, USA.

ANKOM. 2006a. Neutral Detergent Fiber in Feeds. Filter Bag Technique. ANKOM Technology Method 6. Macedon, NY, USA.

ANKOM. 2006b. Acid Detergent Fiber in Feeds. Filter Bag Technique. ANKOM Technology Method 5. Macedon, NY, USA.

ANKOM. 2008. Crude Fiber Analysis in Feeds By Filter Bag Technique. AOCS Approved Procedure Ba 6a-05, ANKOM Technology Method 7. Macedon, NY, USA.

ANKOM. 2009. Rapid Determination of Oil/Fat Utilizing High Temperature Solvent Extraction. ANKOM Technology Method 2, AOCS Official Procedure Am 5-04. Macedon, NY, USA.

Ansorena, J. 1994. Sustratos. Propiedades y Caracterización. Ed. Mundi-Prensa, S.A., Madrid, España.

Benavides, J.S., Herrera, J.C. 2009. Reconocimiento de las características del género Pleurotus spp. y sus aplicaciones. Colegio Seminario Redentorista San Clemente Maria Hofbauer, Manizales, Colombia.

Brizuela, M.A., García, L., Pérez, L., Mansur, M. 1998. Basidiomicetos: nueva fuente de metabolitos secundarios. Revista Iberoamericana de Micología 15: 69-74.

Chang, S.T. and P., Miles, 1997. Biología de las Setas. Fundamentos Básicos y Acontecimientos Actuales. World Scientific. Hong-Kong, China.

Delmas, J. 1989. Les Champignons et Leur Culture. Ed. Flammarion-La Maison Rustique, Paris, France.
Fonseca, G.G., Avila, E., Fossati, L., Antunes, A.P., Vieira, J.A. 2009. Protein enrichment and digestibility of soft rush (Juncus effusus) and rice residues using edible mushrooms Pleurotus ostreatus and Pleurotus sajor-caju. World J. Microbiol. Biotechnol. 25, 449-456.

Forero, C.L., Hoyos, O.L., Bazante, W.E. 2008. Evaluación de residuos de ají (Capsicum spp.) como sustrato en la producción de setas comestibles (Pleurotus ostreatus). Facultad de Ciencias Agropecuarias. 6: 42-53.

García Rollán, M. 2007. Cultivo de Setas y Trufas. Quinta Edición. Mundi - Prensa, S. A., Madrid, España.

Gea, F.J., Martínez-Carrasco, A., Navarro, M.J. 2009. Efecto de la suplementación del sustrato sobre la cosecha de setas. Horticultura Internacional. 67, $32-40$.

González, J., Alvira, P., González, G. 1987. La cascarilla de arroz en la alimentación animal. II Composición químico-bromatológica. Revista de Agroquímica y Tecnología de Alimentos. 27, 139-149.

Gregori, A., Svagelj, M., Pahor, B., Berovic, M., Pohleven, F. 2008. The use of spent brewery grains for Pleurotus ostreatus cultivation and enzyme production. New Biotechnology. 25, 157161.

Hassan, F.R.H., Medany, G.M., Abou Hussein, S.D. 2010. Cultivation on the king oyster mushroom (Pleurotus eryngii) in Egypt. Aust. J. Basic \& Appl. Sci. 4, 99-105.

Ilbay, M.E. 2004. Pleurotus eryngii (De Candolle: Fries) Quetlet yetiştiriciliginde degişik katki maddelerinin verim ve kaliteye etkileri üzerine araştirmalar. VII. National Edible Mushroom Congress, Antalya, Turquía.

Kachlisvili, E., Penninckx, M.J. Tsiklauri, N., Elisashvili, V. 2005. Effect of nitrogen source on lignocellulosic enzyme production by 
white-rot basidiomycetes under solid-state cultivation. World Journal of Microbiology and Biotechnology. 22,391-397.

Krantz, G.W. 1986. A Manual of Acarology, $2^{\text {nd }}$ Ed. Oregon St. Univ. Book Stores, Inc., Corvallis, OR, USA.

Kurt, S., Buyukalaca, S. 2010. Yield performances and changes in enzyme activities of Pleurotus spp. (P. ostreatus and P. sajor-caju) cultivated on different agricultural wastes. Bioresource Technol. 101, 3.164-3.169.

Mandeel, Q.A., Al-Laith, A.A., Mohamed, S.A. 2005. Cultivation of oyster mushrooms (Pleurotus spp.) on various lignocellulosic wastes. World Journal of Microbiology and Biotechnology. 21, 601-607.

Manzi, P., Gambelli, L., Marconi, S., Vivanti, V., Pizzoferrato, L. 1999. Nutrients in edible mushrooms: an interspecies comparative study. J. Food Chem. 65, 477-482.

MAPA, 1994. Métodos Oficiales de Análisis. Tomo III. Servicio de Publicaciones del Ministerio de Agricultura, Pesca y Alimentación, Madrid, España.

Nombela, G., Bello, A. 1983. Modificaciones al método de extracción de nematodos fitoparásitos por centrifugación en azúcar. Boletín del Servicio de Plagas. 9, 183-189.

Oyetayo, F.L., Akindahunsi, A.A. 2004. Nutrient distribution in wild and cultivated edible mushroom, Pleurotus sajo-caju. J. Food Agr. Environ. 2, 166-168.

Pardo, A., Perona, M.A., Pardo, J. 2005a. Evaluación de nuevos materiales en la elaboración de sustratos específicos para el cultivo de Pleurotus ostreatus (Jacq. ex Fr.) Kummer. Cuadernos de Fitopatología. 85, 77-83.
Pardo, A., Perona, M.A., Pardo, J. 2005b. Utilización de raspón de uva en la elaboración de sustratos específicos para el cultivo de Pleurotus ostreatus (Jacq. ex Fr.) Kummer. ITEA 101: 59-69.

Pardo, A., Perona, M.A., Pardo, J. 2007. Nuevos materiales y tratamientos en la elaboración de sustratos para cultivo de Pleurotus ostreatus (Jacq. ex Fr.) Kummer. Cuadernos de Fitopatología. 91, 7-13.

Pardo, J., Perona, Ma . A., Pardo, A. 2008a. Materiales y técnicas para la elaboración de sustratos de cultivo de Pleurotus spp. En: Diputación Provincial de Cuenca (Eds.), Actas de las IV Jornadas Técnicas del champiñón y otros hongos comestibles en Castilla - La Mancha, 11-31. Quintanar del Rey, Cuenca, España.

Pardo, A., Perona, M.A., Pardo, J. 2008b. Evaluación de nuevos materiales en la elaboración de sustratos específicos para cultivo de Pleurotus ostreatus (Jacq. ex Fr.) Kummer. Cuadernos de Fitopatología. 85, 77-84.

Picornell, M.R., de Juan, J.A., Pardo, A. 2010. Reutilización de sustratos postcultivo de hongos comestibles en el cultivo de Pleurotus ostreatus (Jacq.) P. Kumm. Tesis Doctoral. Escuela Técnica Superior de Ingenieros Agrónomos de Albacete, Universidad de Castilla - La Mancha, España.

Rinker, D.L. 2002. Handling and using "spent" mushroom substrate around the world. In: J.E. Sánchez, G. Huerta, E. Montiel (Eds.), Mushroom Biology and Mushroom Products. Universidad Autónoma del Estado de Morelos, Cuernavaca, México. p. 43-60.

Rodríguez Barreal, J.A. 1987. El pleurotus ostreatus, hongo comestible: su cultivo sobre sustratos lignocelulósicos. Ed. Fundación Conde del Valle de Salazar, Escuela Técnica Superior de Ingenieros de Montes, Madrid. 
Rodríguez Estrada, A.E., Jiménez-Gasco, $\mathrm{M}^{\mathrm{a}}$. M., Royse, D.J. 2009. Improvement of yield of Pleurotus eryngii var. eryngii by substrate supplementation and use of a casing overlay. Bioresource Technology. 100, 5.270-5.276.

Sánchez, C. 2010. Cultivation of Pleurotus ostreatus and other edible mushrooms. Appl. Microb. Biot. $85,1.321-1.337$.

Siwulski, M., Czerwinska-Nowak, A., Korszun, S. 2009. Effect of addition of maidenhair tree leaves to substrate on yielding and chemical composition of Pleurotus ostreatus (Fr.) Kumm. carpophores. Vegetable Crops Research Bulletin. 71, 103-109.

SPSS. 2004. SPSS ${ }^{\circledR} 13.0$ Brief Guide. SPSS, Chicago, ILL, USA.

Statistical Graphics Corporation. 2001. Statgraphics Plus $^{\circledR} 5.1$ for Windows, Statistical Graphics Corporation, Herndon, Virginia, VA, USA.
TECATOR, 1987. Determination of Kjeldahl Nitrogen Content with the Kjeltec Auto 1030 Analyzer. Tecator Application Note 30/87, Hönagäs, Sweden.

Varnero, M.T., Quiroz, M.S., Álvarez, C.H. 2010. Utilización de residuos forestales lignocelulósicos para producción del Hongo Ostra (Pleurotus ostreatus). Información Tecnológica. 21, 13-20.

Vijay, M., Shyam, P., Abrar, S., Mirza, B. 2007. Bioconversion of low quality lignocellulosic agricultural waste into edible protein by Pleurotus sajor-caju (Fr.) Singer. J. Zhejiang Univ Sci. 8, 745-751.

Zadrazil, F. 1980a. Influence of ammonium nitrate and organic supplements on the yield of Pleurotus sajor-caju (Fr.) Sing. European Journal of Applied Microbiology and Biotechnology. 9, 31-35.

Zadrazil, F. 1980b. Conversion of different plant wastes into feed by basidiomycetes. European Journal of Applied Microbiology and Biotechnology. 9, 243-248. 